\title{
PASSIVE AIR SAMPLING OF PERSISTENT ORGANIC POLLUTANTS IN TWO ESTONIAN AIR MONITORING STATIONS
}

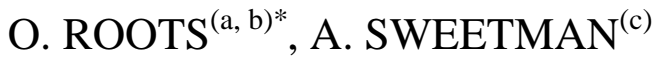 \\ (a) Estonian Environmental Research Institute \\ (under Estonian Environment Research Centre) \\ 4D Marja Str., 10617 Tallinn, Estonia \\ (b) Estonian Marine Institute \\ University of Tartu \\ 10A Mäealuse Str., 12618 Tallinn, Estonia \\ (c) Department of Environmental Science \\ Institute of Environmental and Natural Sciences \\ Lancaster University \\ LA1 4YQ, UK
}

\begin{abstract}
The Environmental Chemistry and Ecotoxicology Group of Lancaster University, United Kingdom, has completed a large European-scale air sampling campaign within the framework of the project, POPs Fate Modelling. Samplers were deployed at remote, rural and urban locations (71 stations) in 22 countries, two Estonian stations - Lahemaa-background EMEP station and Kohtla-Järve industrial (oil shale chemistry) region station - among them. This paper presents data on a range of polychlorinated biphenyls (PCBs), polycyclic aromatic hydrocarbons (PAHs), organochlorine pesticides (hexachlorocyclobenzene $(\mathrm{HCB})$, hexachlorocyclohexane (HCH), ppDDE, ppDDT), polybrominated diphenyl ethers (PBDEs) and polychlorinated naphthalenes (PCN) determined in ambient air samples collected at Estonian stations.
\end{abstract}

\section{Introduction}

The atmosphere is an important contributor of anthropogenic matter to the land and marine ecosystems. Environmentally hazardous substances, such as persistent organic pollutants (POPs), are acutely toxic, persistent and bioaccumulative (i.e. they become concentrated in food chains reaching toxic levels). Because of slow rates of chemical, photochemical and biological

\footnotetext{
*Corresponding author: email Ott.Roots@klab.ee
} 
degradation, persistent organic pollutants (such as PCB, HCB, DDT, $\gamma-\mathrm{HCH}$, etc.) provide excellent model compounds to study atmospheric transport processes of organic pollutants. Passive air samplers with PolyUrethane Foam (PUF) filters are suitable for monitoring of some types of POPs, particularly highly volatile compounds from the group of polycyclic aromatic hydrocarbons (PAHs; acenaphtylene - pyrene), polychlorinated biphenyls (PCBs) and organochlorinated pesticides (OCPs). Compounds of lesser volatility (for example high-molecular PAHs) also collected on the filter are only partially (sorbed on catched dust particles) detectable [1-4]. Low sensitivity to accidental short-time changes in the concentration of pollutants is a basic characteristic of passive samplers. They provide information about the long-term contamination of the studied environmental compartment (for example the air). The air streams freely around a filter, membrane or other medium (sorbent), which captures pollutants during the period of passive air sampling. It is possible to use polyurethane foam (PUF) for sampling persistent organic pollutants (POPs) [2-4].

Passive air sampling is a cheap screening method for comparison of contamination at various sites or for verification of information obtained by active samplers. During the last years our attention has been drawn to the most toxic and persistent pollutants and so-called new pollutants such as PCN, PBDEs, which were analysed in the Estonian air for the first time. The aim of this article is to inform the people about air pollution situation in Estonia.

\section{Methodology}

The relationship between the amount of POPs captured on a PUF filter and their concentrations in the sampled air has not been mathematically fully described yet. Thus only empirically estimated information (for example based on parallel active and passive measurements) is available to interpret the results. Sampling rates about $3.5 \mathrm{~m}^{3} /$ day were determined by empirical measurements. That makes approximately $100 \mathrm{~m}^{3}$ for a 28-day sampling cycle [2-4].

At present it is very difficult to compare the results of the analyses of persistent organic pollutants (POPs) made in various countries. The only possibility is to collect air samples in individual countries using the same equipment and methods, and to analyse the samples in one laboratory (intercalibrated laboratory). If we analyse the air, aerosols, precipitation pollution, this variant is advisable [1-5].

In 1990-1994 PUFs $(27 \times 40 \mathrm{~mm}$ of colourless polyester, density $30 \mathrm{~kg} / \mathrm{m}^{3}$ ), were used as collection media. Project coordinator was Lund University in Sweden $[1,6]$. About $1000 \mathrm{~m}^{3}$ of the air was drawn through the PUF by means of an electric pump at the rate of $30-50 \mathrm{l} / \mathrm{min}$ (registered by a 
flowmeter). The PUFs were changed for new ones on a 14-day basis, and analysed by the method given in [7].

In 2002, seventy one samplers were successfully deployed across 22 countries (Czech Republic, Cyprus, Poland, Switzerland, Croatia, Estonia, Hungary, Kazakhstan, Iceland, Russia, Finland, Greece, The Netherlands, Norway, Portugal, Sweden, Ireland, France, Germany, Italy, Spain and the UK). Project coordinator was the Environmental Chemistry and Ecotoxicology Group of Lancaster University, United Kingdom. Local volunteers were given guidance on the choice of deployment location. Precleaned and weighed PUF disks $\left(14 \mathrm{~cm}\right.$ diameter, $1.35 \mathrm{~cm}$ thick, density $\left.0.0213 \mathrm{~g} / \mathrm{cm}^{3}\right)$ were used. The samplers are described in [8]. The PUFs were changed after a six-week period (June 15 -July 30, 2002) and analysed by the methods presented in $[2,3]$.

\section{Results and discussion}

Persistent organic pollutants (POPs) are a group of toxic and persistent chemicals whose effect on human health and on the environment includes dermal toxicity, immunotoxicity, reproductive effects and teratogenicity, endocrine disrupting effects and carcinogenicity.

Above the Baltic Sea the concentration of PCB homologues proved to be higher with south-west winds [1, 5, 9]. This endangers Estonian islands Saaremaa (Vilsandi) and Hiiumaa, since these winds are prevailing on the Baltic Sea. This problem was the reason, why at the beginning of the ninetieths we became more interested in the long-range transportation of POPs to Estonia. According to the Order from 21.10.1967 approved by the Government, the import of chlororganic plant protection products was banned in Estonia [10].

In October 1990, a field study was initiated by Lund University, in order to determine PCBs (total 51 identified peaks), DDTs and HCHs in the air and precipitations at 16 sampling stations, in closest surroundings of the Baltic Sea (Tables 1-3). Sampling was carried out continuously during one year. The median concentrations in the air samples for all stations were: $57 \mathrm{pg} / \mathrm{m}^{3}$ for PCBs, $1.6 \mathrm{pg} / \mathrm{m}^{3}$ for DDTs (sum of $p p$ DDE and $p p$ DDT) and $25 \mathrm{pg} / \mathrm{m}^{3}$ for $\mathrm{HCHs}$ (sum of $\alpha-\mathrm{HCH}$ and $\gamma-\mathrm{HCH}$ ). The station in Latvia (Salaspils) showed the highest values of PCBs and DDTs in the air, with a median concentration of $454 \mathrm{pg} / \mathrm{m}^{3}$ of PCBs and $12 \mathrm{pg} / \mathrm{m}^{3}$ of DDTs. Median concentrations of HCHs were highest in two Polish stations (Swibno $103 \mathrm{pg} / \mathrm{m}^{3}$ and Dziwnow $\left.72 \mathrm{pg} / \mathrm{m}^{3}\right)$. At these stations DDT concentrations were high too, 6 and $9 \mathrm{pg} / \mathrm{m}^{3}$, respectively [1].

The analyses on PCB and pesticides, made by Lund University on the samples taken near the Gulf of Riga in the five Baltic air-research stations in Estonia (Vilsandi - Saaremaa and Tahkuse-Western-Estonia) and Latvia (Salaspils, Salacgriva and Slitere) in 1993-94, showed that the air and rain water samples taken in Estonian stations were relatively cleaner compared 
Table 1. Summary of the different PCB concentrations and calculated depositions at the stations [1]

\begin{tabular}{|l|l|l|c|c|}
\hline Latitude & \multicolumn{1}{|c|}{ Station } & Air $\left(\mathrm{pg} / \mathrm{m}^{3}\right)$ & Precipitation $(\mathrm{ng} / \mathrm{L})$ & Deposition $\left(\mathrm{ng} / \mathrm{m}^{2} \mathrm{~d}\right)$ \\
\hline $54^{\circ} 00^{\prime}$ & Dziwnow & $55(\mathrm{n}=5)$ & $1.4(\mathrm{n}=2)$ & $2.3(\mathrm{n}=2)$ \\
$54^{\circ} 15^{\prime}$ & Swibno & $69(\mathrm{n}=6)$ & $4.4(\mathrm{n}=4)$ & $5.0(\mathrm{n}=4)$ \\
$55^{\circ} 25^{\prime}$ & Ventes R. & $61(\mathrm{n}=10)$ & $2.0(\mathrm{n}=15)$ & $3.7(\mathrm{n}=15)$ \\
$56^{\circ} 14^{\prime}$, & Öland & $76(\mathrm{n}=21)$ & $8.3(\mathrm{n}=15)$ & $3.5(\mathrm{n}=15)$ \\
$56^{\circ} 17$, & Breanäs & $79(\mathrm{n}=21)$ & $2.8(\mathrm{n}=12)$ & $2.8(\mathrm{n}=12)$ \\
$56^{\circ} 50^{\prime}$ & Salaspils & $454(\mathrm{n}=20)$ & $10.7(\mathrm{n}=15)$ & $17.9(\mathrm{n}=15)$ \\
$58^{\circ} 20^{\prime}$ & Vilsandi & $79(\mathrm{n}=9)$ & $1.5(\mathrm{n}=9)$ & $2.2(\mathrm{n}=9)$ \\
$58^{\circ} 21^{\prime}$ & Gotska s. & $60(\mathrm{n}=24)$ & $2.0(\mathrm{n}=15)$ & $3.0(\mathrm{n}=15)$ \\
$59^{\circ} 17^{\prime}$, & Stockholm s. & $80(\mathrm{n}=21)$ & $1.3(\mathrm{n}=10)$ & $2.4(\mathrm{n}=10)$ \\
$59^{\circ} 30^{\prime}$ & Lahemaa & $49(\mathrm{n}=16)$ & $0.8(\mathrm{n}=12)$ & $1.8(\mathrm{n}=12)$ \\
$63^{\circ} 02^{\prime}$ & Vasa & $32(\mathrm{n}=27)$ & $0.9(\mathrm{n}=12)$ & $1.2(\mathrm{n}=12)$ \\
$63^{\circ} 03$, & Docksta & $50(\mathrm{n}=24)$ & $1.8(\mathrm{n}=15)$ & $2.6(\mathrm{n}=15)$ \\
$63^{\circ} 32^{\prime}$, & Norrbyn & $48(\mathrm{n}=24)$ & $1.8(\mathrm{n}=17)$ & $3.2(\mathrm{n}=14)$ \\
$63^{\circ} 36$ & Holmögadd & $57(\mathrm{n}=23)$ & $4.9(\mathrm{n}=12)$ & $5.7(\mathrm{n}=12)$ \\
$64^{\circ} 31^{\prime}$, & Bjuröklubb & $38(\mathrm{n}=24)$ & $2.9(\mathrm{n}=13)$ & $2.2(\mathrm{n}=13)$ \\
$65^{\circ} 44^{\prime}$ & Kalix & $47(\mathrm{n}=24)$ & $2.4(\mathrm{n}=14)$ & $1.5(\mathrm{n}=14)$ \\
\hline Average of all stations & $57(\mathrm{n}=299)$ & $2.3(\mathrm{n}=192)$ & $2.7(\mathrm{n}=192)$ \\
\hline
\end{tabular}

Table 2. Summary data on DDT concentration in the air and in depositions [1]

\begin{tabular}{|l|l|l|l|l|}
\hline Latitude & \multicolumn{1}{|c|}{ Station } & Air $\left(\mathrm{pg} / \mathrm{m}^{3}\right)$ & Precipitation $(\mathrm{ng} / \mathrm{L})$ & Deposition $\left(\mathrm{ng} / \mathrm{m}^{2} \mathrm{~d}\right)$ \\
\hline $54^{\circ} 00^{\prime}$ & Dziwnow & $9.0(\mathrm{n}=5)$ & $0.21(\mathrm{n}=2)$ & $0.30(\mathrm{n}=2)$ \\
$54^{\circ} 15^{\prime}$ & Swibno & $6.3(\mathrm{n}=6)$ & $1.24(\mathrm{n}=3)$ & $1.0(\mathrm{n}=3)$ \\
$55^{\circ} 25^{\prime}$ & Ventes R. & $2.3(\mathrm{n}=10)$ & $0.18(\mathrm{n}=15)$ & $0.38(\mathrm{n}=15)$ \\
$56^{\circ} 14^{\prime}$, & Öland & $5.1(\mathrm{n}=21)$ & $0.71(\mathrm{n}=13)$ & $0.38(\mathrm{n}=13)$ \\
$56^{\circ} 17^{\prime}$ & Breanäs & $3.3(\mathrm{n}=20)$ & $0.17(\mathrm{n}=12)$ & $0.19(\mathrm{n}=12)$ \\
$56^{\circ} 50^{\prime}$, & Salaspils & $12.4(\mathrm{n}=20)$ & $0.40(\mathrm{n}=15)$ & $0.64(\mathrm{n}=15)$ \\
$58^{\circ} 20^{\prime}$ & Vilsandi & $6.9(\mathrm{n}=8)$ & $0.28(\mathrm{n}=5)$ & $0.23(\mathrm{n}=5)$ \\
$58^{\circ} 21^{\prime}$, & Gotska s. & $2.0(\mathrm{n}=24)$ & $0.15(\mathrm{n}=15)$ & $0.19(\mathrm{n}=15)$ \\
$59^{\circ} 17^{\prime}$, & Stockholm s. & $2.0(\mathrm{n}=21)$ & $0.09(\mathrm{n}=10)$ & $0.12(\mathrm{n}=10)$ \\
$59^{\circ} 30^{\prime}$ & Lahemaa & $2.0(\mathrm{n}=16)$ & $0.06(\mathrm{n}=12)$ & $0.1(\mathrm{n}=12)$ \\
$63^{\circ} 02^{\prime}$, & Vasa & $0.8(\mathrm{n}=26)$ & $0.03(\mathrm{n}=12)$ & $0.05(\mathrm{n}=12)$ \\
$63^{\circ} 03^{\prime}$ & Docksta & $1.2(\mathrm{n}=24)$ & $0.08(\mathrm{n}=15)$ & $0.08(\mathrm{n}=15)$ \\
$63^{\circ} 32^{\prime}$, & Norrbyn & $0.9(\mathrm{n}=24)$ & $0.07(\mathrm{n}=16)$ & $0.09(\mathrm{n}=16)$ \\
$63^{\circ} 36^{\prime}$ & Holmögadd & $1.2(\mathrm{n}=22)$ & $0.18(\mathrm{n}=8)$ & $0.16(\mathrm{n}=8)$ \\
$64^{\circ} 31^{\prime}$ & Bjuröklubb & $0.7(\mathrm{n}=22)$ & $0.04(\mathrm{n}=11)$ & $0.05(\mathrm{n}=11)$ \\
$65^{\circ} 44^{\prime}$ & Kalix & $0.9(\mathrm{n}=24)$ & $0.07(\mathrm{n}=14)$ & $0.05(\mathrm{n}=14)$ \\
\hline Average of all stations & $1.6(\mathrm{n}=281)$ & $0.13(\mathrm{n}=178)$ & $0.15(\mathrm{n}=178)$ \\
\hline
\end{tabular}


Table 3. Summary data on $\mathrm{HCH}$ concentration in the air and in depositions [1]

\begin{tabular}{|l|l|l|l|c|}
\hline Latitude & \multicolumn{1}{|c|}{ Station } & Air $\left(\mathrm{pg} / \mathrm{m}^{3}\right)$ & Precipitation $(\mathrm{ng} / \mathrm{L})$ & Deposition $\left(\mathrm{ng} / \mathrm{m}^{2} \mathrm{~d}\right)$ \\
\hline $54^{\circ} 00^{\prime}$ & Dziwnow & $72(\mathrm{n}=5)$ & $0.63(\mathrm{n}=2)$ & $1.4(\mathrm{n}=2)$ \\
$54^{\circ} 15^{\prime}$ & Swibno & $103(\mathrm{n}=6)$ & $8.65(\mathrm{n}=3)$ & $5.7(\mathrm{n}=3)$ \\
$55^{\circ} 25^{\prime}$, & Ventes R. & $26(\mathrm{n}=10)$ & $1.63(\mathrm{n}=15)$ & $3.2(\mathrm{n}=15)$ \\
$56^{\circ} 14^{\prime}$, & Öland & $20(\mathrm{n}=21)$ & $2.5(\mathrm{n}=13)$ & $0.98(\mathrm{n}=13)$ \\
$56^{\circ} 17^{\prime}$, & Breanäs & $45(\mathrm{n}=21)$ & $1.8(\mathrm{n}=12)$ & $1.9(\mathrm{n}=12)$ \\
$56^{\circ} 50^{\prime}$ & Salaspils & $39(\mathrm{n}=20)$ & $1.3(\mathrm{n}=15)$ & $2.5(\mathrm{n}=15)$ \\
$58^{\circ} 20^{\prime}$ & Vilsandi & $33(\mathrm{n}=28)$ & $2.1(\mathrm{n}=5)$ & $3.7(\mathrm{n}=5)$ \\
$58^{\circ} 21^{\prime}$, & Gotska s. & $45(\mathrm{n}=24)$ & $1.4(\mathrm{n}=15)$ & $2.2(\mathrm{n}=15)$ \\
$59^{\circ} 17^{\prime}$, & Stockholm s. & $24(\mathrm{n}=21)$ & $1.0(\mathrm{n}=10)$ & $1.3(\mathrm{n}=10)$ \\
$59^{\circ} 30^{\prime}$ & Lahemaa & $26(\mathrm{n}=16)$ & $0.31(\mathrm{n}=12)$ & $0.53(\mathrm{n}=12)$ \\
$63^{\circ} 02^{\prime}$, & Vasa & $30(\mathrm{n}=16)$ & $0.38(\mathrm{n}=12)$ & $1.3(\mathrm{n}=12)$ \\
$63^{\circ} 03^{\prime}$, & Docksta & $18(\mathrm{n}=24)$ & $0.92(\mathrm{n}=15)$ & $1.7(\mathrm{n}=15)$ \\
$63^{\circ} 32^{\prime}$, & Norrbyn & $7(\mathrm{n}=24)$ & $0.16(\mathrm{n}=17)$ & $0.61(\mathrm{n}=17)$ \\
$63^{\circ} 36^{\prime}$ & Holmögadd & $20(\mathrm{n}=23)$ & $1.3(\mathrm{n}=8)$ & $0.82(\mathrm{n}=8)$ \\
$64^{\circ} 31^{\prime}$, & Bjuröklubb & $28(\mathrm{n}=15)$ & $0.46(\mathrm{n}=10)$ & $0.22(\mathrm{n}=10)$ \\
$65^{\circ} 44^{\prime}$ & Kalix & $4(\mathrm{n}=21)$ & $0.33(\mathrm{n}=14)$ & $0.16(\mathrm{n}=14)$ \\
\hline Average & of all stations & $25(\mathrm{n}=275)$ & $1.0(\mathrm{n}=178)$ & $1.3(\mathrm{n}=178)$ \\
\hline
\end{tabular}

with the samples taken in Latvia [1, 5, 6]. Currently, the movement of some POPs, for example PCB, from afar from southern sources outside Estonia is highly significant (Fig. 1). The results were further treated by principal component analysis (PCA), and it was shown that PCB in air samples near the town of Riga (Latvia) originated from the original industrial PCB mixture. The sources of POPs contaminating the atmosphere over Saaremaa-Vilsandi are thus not situated in the near-by areas [6]. This refers either to the long-range transportation or the local waste centre situated near the Gulf of Riga (Fig. 1). Geometrical mean concentrations of chlororganic pesticides were: $\alpha-\mathrm{HCH}$ $5-17 \mathrm{pg} / \mathrm{m}^{3}, \gamma-\mathrm{HCH}-0.3-4 \mathrm{pg} / \mathrm{m}^{3}$ and $\mathrm{HCB}-10-38 \mathrm{pg} / \mathrm{m}^{3}[6]$.

At the beginning of 2000, the Estonian partner became more interested in air pollution data from our Estonian oil shale region. In March 2003, dioxin, PAHs and naphthalene emissions from a shale oil producing plant located near the town of Narva in Estonia were measured. The Danish environment assistance to Eastern Europe (DANCEE) has sponsored the project, and dkTEKNIK ENERGY \& ENVIRONMENT (now FORCE Technology) was responsible for measurements, which where conducted in cooperation with Estonian Environmental Research Centre in Tallinn. Analytical results for PAH were handled and presented according to the regulation given in the Danish Air Emission Guidance [11]. This regulation distinguishes between naphthalene and the rest of the 16 EPA PAH, originally selected by U.S. EPA and now widely used internationally to characterize and assess PAH mixtures. The concentrations of naphthalene and PAH were much lower than the Danish emission limit values in Table 4. All the measured concentrations 


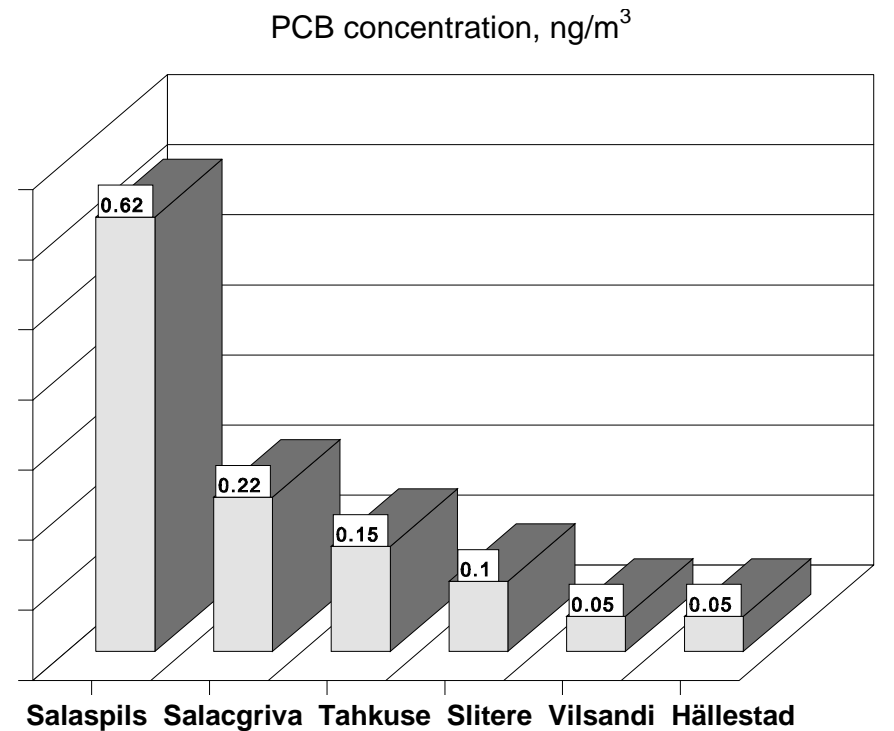

Fig. 1. Atmospheric concentrations of PCB along the route from the town of RigaSalaspils (Latvia) to the island of Saaremaa-Vilsandi (Estonia) in 1993-94 (geometric means for the monitoring stations). Levels recorded at a Swedish station (Hällestad), Estonian station (Tahkuse), Latvian stations (Salacgriva and Slitere) are shown for comparison [by the data 6].

Table 4. PAH and naphthalene emitted from oil plant [12]

\begin{tabular}{|l|l|c|c|}
\hline \multicolumn{1}{|c|}{ Parameter } & \multicolumn{1}{|c|}{ Unit } & $\begin{array}{c}\text { Danish Emission } \\
\text { limit value }\end{array}$ & Measured values \\
\hline Naphthalene & $\mathrm{Mg} / \mathrm{m}^{3}(\mathrm{~s}, \mathrm{~d}, 6 \% \mathrm{O} 2)$ & 300 & 7.5 \\
PAH & $\mathrm{Mg} \mathrm{B}[\mathrm{a}] \mathrm{P}-\mathrm{TEQ} / \mathrm{m}^{3}(\mathrm{n}, \mathrm{t}, 6 \% \mathrm{O} 2)$ & 5.0 & 1.5 \\
\hline
\end{tabular}

of dioxin emission from the oil shale plant were very low, being much lower than the EU emission limit value for MSWI at $0.1 \mathrm{ng} I-\mathrm{TEQ} / \mathrm{m}^{3}(\mathrm{n}, \mathrm{d})$. The total emission of dioxins is estimated to be $0.2 \mathrm{mg} / \mathrm{year}$ into the air and $700 \mathrm{mg} /$ year with ash [12]. The total annual dioxin emission with the ashes is, based on the measurements, considered to be very close to zero.

The total annual dioxin emission from the oil shale-fired Estonian and Baltic Power Plants into the air is estimated to be 160-300 mg I-TEQ [13-15], which is more than ten times lower than previous estimations [16].The total annual dioxin emission with the ashes is considered to be very close to zero, but due to periods with unstable combustion conditions, it could be higher, but nevertheless estimated less than $1 \mathrm{~g}$ [13-15].

At the beginning of 2000, the project Dioxin in Candidate Countries was carried out on behalf and with financial support of the European 
Commission, DG Environment [17]. Overall 30 industrial facilities located in 10 of the 13 Candidate Countries have been proposed for PCDD/F emission measurements. Among these were a number of potentially relavant emission sources like cement works (Estonia, Cyprus, Lithuania), etc. The results of the measurements carried out in Estonia are shown in Table 5.

Table 5. Results of the measurements carried out in Estonia [17]

\begin{tabular}{|c|c|c|c|}
\hline Plant & $\begin{array}{c}\text { PCDD/F concentration } \\
{\left[\mathrm{ng} \mathrm{I-TEQ} / \mathrm{m}^{3}\right]}\end{array}$ & $\begin{array}{c}\text { Annual PCDD/F release } \\
{[\mathrm{mg} \mathrm{I-TEQ} / \text { year] }}\end{array}$ & $\begin{array}{c}\text { Emission factor } \\
{[\mu \mathrm{g} \mathrm{I}-\mathrm{TEQ} / \text { ton }]}\end{array}$ \\
\hline Cement works & 0.018 & 47 & 0.07 \\
\hline
\end{tabular}

During the last years attention has been drawn to the most toxic pollutants and so-called new pollutants, which were analysed in the Estonian air for the first time. Passive sampling of POPs is the topic of many research groups. The Environmental Chemistry and Ecotoxicology Group of Lancaster University, United Kingdom, has just completed a large European-scale air sampling campaign in project POPs Fate Modelling. Samplers (Fig. 2) were deployed at remote, rural and urban locations in 22 countries and samples analysed for PCBs, PAHs, PCNs, PBDEs and organochlorine pesticides $(\mathrm{HCB}, \alpha-\mathrm{HCH}, \gamma-\mathrm{HCH}, p p \mathrm{DDE}, p p \mathrm{DDT})$. Local volunteers were given guidance on the choice of deployment location. Results were presented in two publications $[2,3]$. The Estonian partner was more interested in data about PCNs and PBDEs, because the concentrations of those two toxic compounds were analysed in the Estonian air samples for the first time (Tables 6 and 7). PBDE values in Eastern Europe were generally low. Highest loads were measured in samples from UK. Differences between the highest and lowest (non-detectable) samples are characterized by a factor of 300 [18]. For most samples the ratio PBDE47/PBDE99 ranged from 0.3-1.6 (ng/sample).

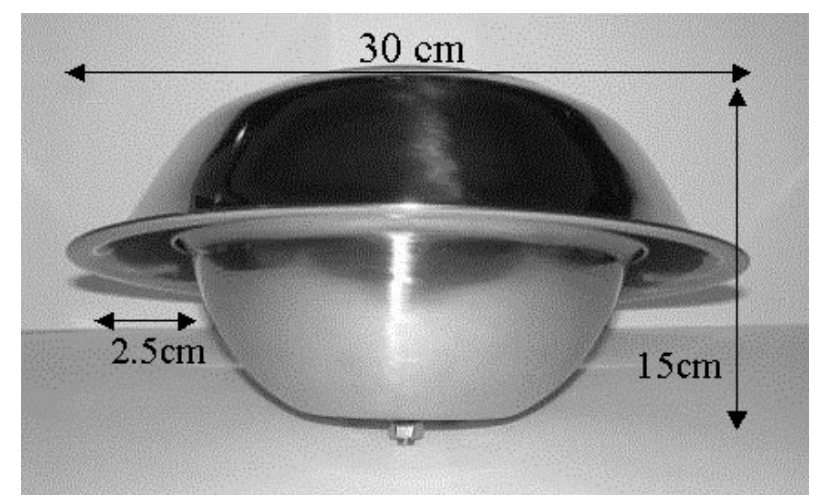

Fig. 2. PUF Photo [2-4]. 
Table 6. Concentrations of persistent organic pollutants measured in Lahemaa and Kohtla-Järve air monitoring stations, Estonia (Sweetman, personal information)

\begin{tabular}{|c|c|c|c|c|}
\hline Measurement site & Kohtla-Järve & Lahemaa & Kohtla-Järve & Lahemaa \\
\hline \multirow[t]{2}{*}{ Sample ID } & 13 & 14 & 13 & 14 \\
\hline & ng/sample & ng/sample & $\mathrm{pg} / \mathrm{m}^{3}$ & $\mathrm{pg} / \mathrm{m}^{3}$ \\
\hline PCB 18 & 10.23 & $<0.48$ & 81.20 & nd \\
\hline PCB 22 & 5.12 & $<0.58$ & 40.66 & nd \\
\hline PCB 28 & 12.61 & $<0.64$ & 100.15 & nd \\
\hline PCB 31 & 10.03 & 0.55 & 79.67 & 4.37 \\
\hline РCB 41/64 & 3.62 & 0.23 & 28.71 & 1.86 \\
\hline PCB 44 & 4.93 & 0.35 & 39.17 & 2.80 \\
\hline PCB 49 & 3.78 & 0.23 & 30.03 & 1.87 \\
\hline PCB 52 & 5.86 & 0.55 & 46.55 & 4.39 \\
\hline PCB 60/56 & 4.07 & 0.26 & 32.34 & 2.07 \\
\hline PCB 70 & 5.71 & 0.45 & 45.34 & 3.55 \\
\hline PCB 74 & 2.96 & 0.20 & 23.50 & 1.61 \\
\hline PCB 87 & 1.80 & 0.23 & 14.30 & 1.82 \\
\hline PCB 90/101 & 3.99 & 0.81 & 31.64 & 6.41 \\
\hline PCB 95 & 2.98 & 0.60 & 23.69 & 4.75 \\
\hline РCB 99 & 2.21 & 0.28 & 17.54 & 2.22 \\
\hline PCB 105 & 1.03 & 0.14 & 8.18 & 1.10 \\
\hline PCB 110 & 3.60 & 0.64 & 28.56 & 5.10 \\
\hline PCB 118 & 2.85 & 0.40 & 22.64 & 3.14 \\
\hline PCB 123 & 0.03 & $<0.03$ & 0.27 & nd \\
\hline PCB 138 & 2.54 & 0.68 & 20.20 & 5.42 \\
\hline PCB 141 & 0.48 & 0.17 & 3.78 & 1.36 \\
\hline PCB 149 & 2.26 & 0.83 & 17.94 & 6.55 \\
\hline PCB 151 & 0.78 & 0.35 & 6.18 & 2.75 \\
\hline PCB $153 / 132$ & 3.19 & 0.92 & 25.35 & 7.32 \\
\hline PCB 158 & 0.25 & 0.05 & 2.00 & 0.40 \\
\hline PCB 170 & 0.20 & $<0.03$ & 1.61 & nd \\
\hline PCB 174 & 0.45 & 0.19 & 3.61 & 1.48 \\
\hline PCB 180 & 0.63 & 0.11 & 5.00 & 0.90 \\
\hline PCB 183 & 0.32 & 0.08 & 2.57 & 0.66 \\
\hline PCB 187 & 0.63 & 0.22 & 5.02 & 1.76 \\
\hline Sum 29 PCBs & 99.17 & 10.41 & 787.41 & 82.65 \\
\hline $\mathrm{a}-\mathrm{HCH}$ & 5.16 & 2.18 & 40.99 & 17.34 \\
\hline g-HCH & 3.79 & 1.92 & 30.11 & 15.23 \\
\hline a-chlordane & 0.23 & 0.11 & 1.81 & 0.85 \\
\hline g-chlordane & $<0.05$ & $<0.05$ & nd & nd \\
\hline $\mathrm{HCB}$ & 3.95 & 2.86 & 31.35 & 22.72 \\
\hline opDDD & 0.63 & $<0.05$ & 5.01 & nd \\
\hline ppDDE & 0.62 & 0.07 & 4.91 & 0.55 \\
\hline pp DDD & 0.28 & $<0.05$ & 2.20 & nd \\
\hline pp DDT & 2.14 & 0.40 & 17.00 & 3.14 \\
\hline ppDDE/ppDDT & 0.29 & 0.17 & 2.29 & 1.38 \\
\hline a-HCH/g-HCH & 1.36 & 1.14 & 10.81 & 9.04 \\
\hline PBDE 28 & 0.14 & 0.07 & 1.13 & 0.55 \\
\hline PBDE 47 & 1.75 & 1.52 & 13.89 & 12.07 \\
\hline PBDE 49 & 0.09 & $<0.06$ & 0.68 & nd \\
\hline PBDE 75 & 0.07 & $<0.06$ & 0.53 & nd \\
\hline
\end{tabular}


Table 6 continued

\begin{tabular}{|l|c|c|c|c|}
\hline Measurement site & Kohtla-Järve & Lahemaa & Kohtla-Järve & Lahemaa \\
\hline Sample ID & 13 & 14 & 13 & 14 \\
\hline & ng/sample & ng/sample & $\mathrm{pg} / \mathrm{m}^{3}$ & $\mathrm{pg} / \mathrm{m}^{3}$ \\
\hline PBDE 99 & $<1.47$ & 3.18 & $\mathrm{nd}$ & 25.29 \\
PBDE 100 & $<0.29$ & 0.56 & $\mathrm{nd}$ & 4.42 \\
PBDE 153 & $<0.09$ & 0.36 & $\mathrm{nd}$ & 2.87 \\
PBDE 154 & $<0.1$ & 0.26 & $\mathrm{nd}$ & 2.10 \\
\hline Sum PBDEs & 3.02 & 6.02 & 23.97 & 47.77 \\
\hline
\end{tabular}

Table 7. Concentration of polycyclic aromatic hydrocarbons measured in Lahemaa and Kohtla-Järve air monitoring stations, Estonia (Sweetman, personal information)

\begin{tabular}{|l|c|c|}
\hline \multicolumn{1}{|c|}{ Measurement site } & Kohtla-Järve & Lahemaa \\
\hline \multicolumn{1}{|c|}{ Sampler } & EC 17 & EC 18 \\
\hline \multicolumn{1}{|c|}{ Sample ID } & 13 & 14 \\
\hline Naphthalene & $\mathrm{ng} / \mathrm{m}^{3}$ & $\mathrm{ng} / \mathrm{m}^{3}$ \\
2-methylnaphthalene & 1.10 & 0.73 \\
1-methylnaphthalene & 0.80 & 0.48 \\
Biphenyl & 0.48 & 0.31 \\
2.6-dimethylnaphthalene & 1.49 & 0.75 \\
Acenaphthylene & 0.33 & 0.17 \\
Acenaphthene & 0.14 & 0.02 \\
2.3.6-trimethylnaphthal & 0.20 & 0.07 \\
Fluorene & 0.29 & 0.05 \\
Phenanthrene & 0.94 & 0.17 \\
Anthracene & 7.00 & 0.81 \\
1-methylphenanthrene & 0.21 & 0.02 \\
Fluoranthene & 1.07 & 0.12 \\
Pyrene & 2.53 & 0.29 \\
Benzo(a)anthracene & 2.24 & 0.16 \\
Chrysene & 0.23 & 0.01 \\
Benzo(b)fluoranthene & 0.53 & 0.04 \\
Benzo(k)fluoranthene & 0.15 & 0.01 \\
Benzo(e)pyrene & 0.12 & 0.01 \\
Benzo(a)pyrene & 0.16 & 0.01 \\
Perylene & 0.06 & $<0.005$ \\
Indeno(123-cd)pyrene & 0.01 & $<0.005$ \\
Dibenz(ah)anthracene & 0.04 & $<0.005$ \\
Benzo(ghi)perylene & 0.01 & $<0.005$ \\
PCNs all nd & 0.08 & $<0.005$ \\
\hline & & \\
\hline & & \\
\hline & & \\
\hline
\end{tabular}

For most Eastern European countries the ratio was about 0.5 [2, 3, 18]. For Estonian samples the ratio was 1.19 for Kohtla-Järve and 0.48 for Lahemaa. 
PCNs were generally detected in fewer samples. Highest levels were detected in the UK, Poland, Russia and Czech Republic [18]. Higher $\alpha-\mathrm{HCH}$ and $\gamma-\mathrm{HCH}$ levels generally occured in South and East Europe.

The highest levels of PCB were measured in urban sites in Russia, France, Italy, Sweden, the United Kingdom, and Eastern Europe (Croatia, Hungary, Estonia (at Kohtla-Järve site the sum of $29 \mathrm{PCBs}$ was $787.41 \mathrm{pg} / \mathrm{m}^{3}-$ $99.17 \mathrm{ng} / \mathrm{sample})$. For most samples, the levels for the sum of $29 \mathrm{PCBs}$ ranged from 2.5 to $280 \mathrm{ng} / \mathrm{sample}$ [2]. During the last year attention has been drawn to PCBs in Estonian sewage waters [20, 21]. Effluents from the Järve Biological Sewage Purification station at Kohtla-Järve were analysed on PCB first in 2006 (Fig. 3). As for three sewage water samples from Järve Purification Station effluents to the Gulf of Finland, in two of them PCB

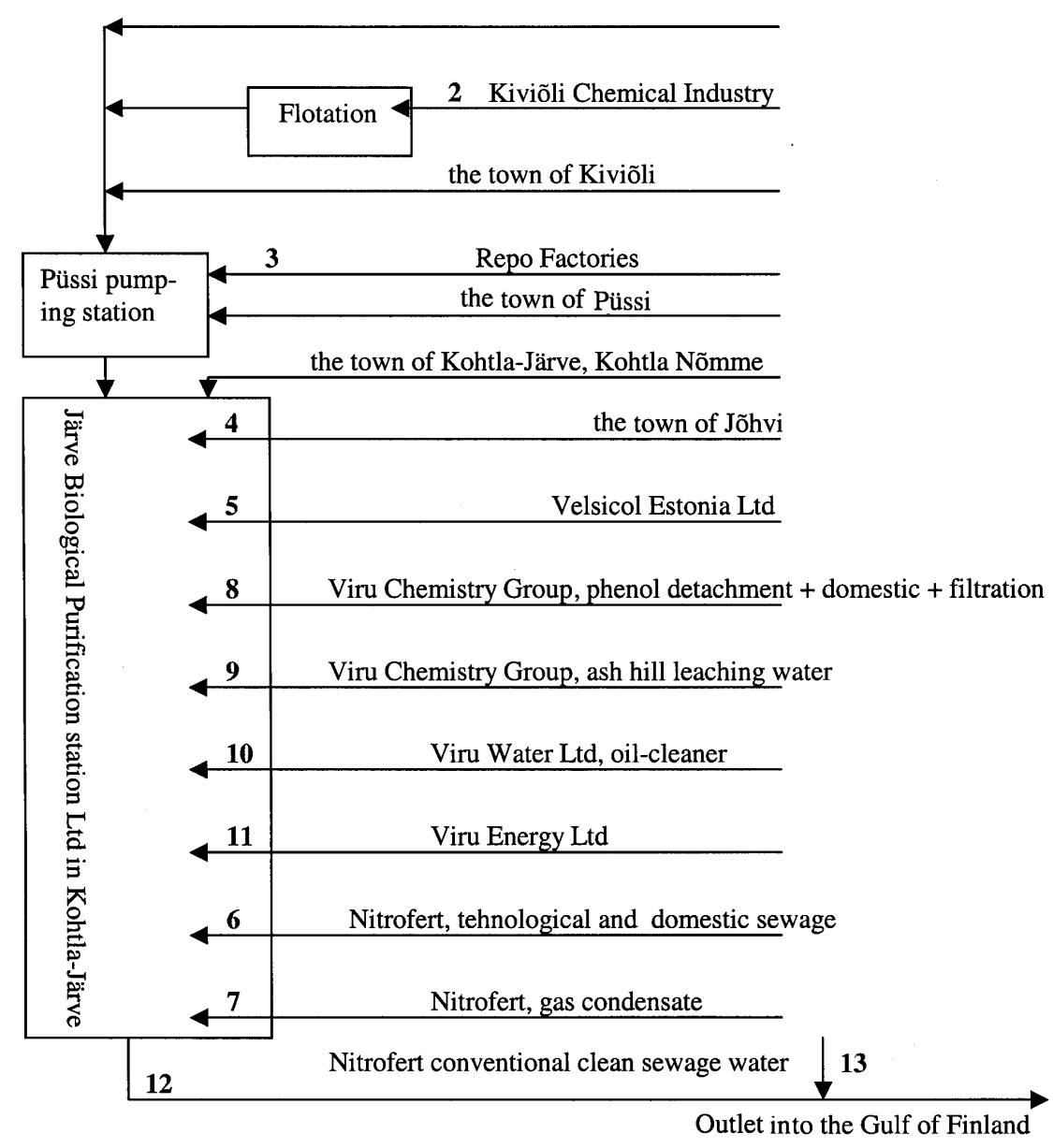

Fig. 3. Scheme of the Järve Biological Sewage Purification Station in Kohtla-Järve [19]. 
concentration exceeded $(95.1$ and $103.0 \mu \mathrm{g} / \mathrm{l})$ Estonian limits for PCB in sewage waters $(50 \mu \mathrm{g} / \mathrm{l})$. The authors propose to organize there a local continuous monitoring station for control over hazardous substances, especially for persistent organic pollutants, in the next future [20].

The geographical pattern of all compounds reflected suspected regional emission patterns and highlighted localised hotspots [2, 3].

\section{Conclusions}

Concentrations of persistent organic pollutants were measured repeatedly at Estonian Lahemaa back-ground station and for the first time at Kohtla-Järve industrial region's air monitoring stations. The authors propose to organize in the next future a local continuous sewage water monitoring station for hazardous substance control, especially for persistent organic pollutants, at Järve Biological Sewage Purification station in Kohtla-Järve [20].

Positive information for us was that PCN (12 isomers) concentrations in the samples of Estonian two air stations were below practical detection limit ( 0.003 to $1.4 \mathrm{ng} / \mathrm{sample}$ for PCNs) [3]. PBDE values in Eastern Europe were generally low.

Emissions of dioxin, PAHs and naphthalene measured in Estonian oil shale chemistry region (Estonian and Baltic power plants, and a shale oil producing plant and cement factory, located near the towns of Narva and Kunda) were considered to be very low [12-15].

\section{REFERENCES}

1. Agrell, G., Larsson, P., Okla, L., Bremle, G., Johansson, N., Klavins, M., Roots, O., Zelechowska, A. Atmospheric and river input of PCBs, DDTs and HCHs to the Baltic Sea // A System Analysis of the Baltic Sea / F. Wulff, L. Rahm, P. Larsson (eds.). Ecological Studies, Springer Verlag, 2001. Vol. 148. P. 149-175.

2. Jaward F. M., Farrar, N. J., Harner, T., Sweetman, A. J., Jones, C. K. Passive air sampling of PCBs, PBDEs, and organochlorine pesticides across Europe // Environ. Sci. Technol. 2004.Vol. 38, No. 1. P. 34-41.

3. Jaward F. M., Farrar, N.J., Harner, T., Sweetman, A. J., Jones, C. K. Passive air sampling of polycyclic aromatic hydrocarbons and polychlorinated naphthalenes across Europe // Environ. Toxicol. Chem.. 2004.Vol. 23, No. 6. P. 1355-1364.

4. Kohoutek, J., Holoubek, I., Klanova, J. Methodology of Passive Sampling. - TOCOEN, s.r.o. Brno/RECETOX MU Brno. TOCOEN REPORT. 2006. No. 300. P. 1-14.

5. Roots, $O$. Organochlorine pesticides and polychlorinated biphenyls in the ecosystem of the Baltic Sea // Chemosphere. 1995. Vol. 31, No. 9. P. 4085-4097.

6. Nordic. Environmental Research Programme for 1993-1997// Final report and selfevaluation. Nordic Council of Ministers. TemaNord ENVIRONMENT. 1999. Vol. 548. P. 135-140.

7. Bremle, G., Okla, L., Larsson, P. Uptake of PCBs in fish in contaminated river system: bioconcentration factors measured in the field // Environ. Sci. Technol. 1995. Vol. 29, No. 2. P. 2010-2015. 
8. Shoeib, M., Harner, T. Characterization and comparison of three passive air samplers for persistent organic pollutants // Environ. Sci. Technol. 2002. Vol. 36, P. 4142-4151.

9. Duinker, J., Bouchertall, F. On the distribution of atmospheric polychlorinated biphenyls congeners between vapor phase, aerosols and rain// Environ. Sci. Technol. 1989. Vol. 23, No. 1. P. 57-62.

10. Müür, J. Plant protection products use in Estonia// Estonian Environment 1995 / E. Meikas (ed.). Environment Information Centre, 1996. P. 66-68.

11. Guidances for air emission regulation. Limitation of air pollution from installations. Environmental Guidelines. 2002. No. 1. Available from the Danish EPA homepage: http://www.mst.dk/udgiv/Publications/2002/87-7972-035-8/pdf/87-7972-036-6.PDF

12. Schleicher, O., Jensen, A., Roots, O., Herrmann, T., Tordik, A. Dioxin and PAH emissions from a shale oil processing plant in Estonia // Organohalogen. Compounds. 2004. Vol. 66. P. 1665-1671.

13. Roots, $O$. Polychlorinated biphenyls (PCB), polychlorinated dibenzo-p-dioxins (PCDD) and dibenzofurans (PCDF) in oil shale and fly ash from oil shale-fired power plant in Estonia // Oil Shale. 2004. Vol. 21, No. 4. P. 333-339.

14. Schleicher, O., Jensen, A., Roots, O., Herrmann, T., Tordik, A. Dioxin emission from two oil shale fired power plants in Estonia // Organohalogen. Compounds. 2004. Vol. 66. P. 4089-4095.

15. Schleicher, O., Roots, O., Jensen, A. A., Herrmann, T., Tordik, A. Dioxin emission from two oil shale-fired power plants in Estonia // Oil Shale. 2005. Vol. 22, No. 4. P. $563-$ 570.

16. Larssen, C., Hansen, E., Jensen, A. A., Olendrynski, K., Kolsut, W., Zurek, J., Kangulewicz, I., Debski, B., Skolkiewicz, J., Holtzer, M., Grochowalski, A., Brante, E., Poltimäe, H., Kallaste, T., Kapturauskas, J. Survey of dioxin sources in the Baltic Region // Environ. Sci. \& Pollut. Res. 2003. Vol. 10. P. 49-56.

17. Quass, U., Pulles, T., Kok, H. The DG Environment project "Dioxin Emissions in Candidate Countries": Scope, approach and first results // Organohalogen. Compounds, 2004. Vol. 66. P. 878-883.

18. Jaward, F. M., Farrar, N. J., Harner, T., Prevedouros, C., Sweetman, A. J., Jones, C. K. Atmospheric PBDEs and PCNs across Europe: results of a passive sampling programme // Organohalogen. Compounds. 2003. Vol. 62. P. 1-4.

19. Analysis of hazardous substances in industrial sewages entering the receiving chamber of the sewage treatment plant of Järve Biotreatment (Compiled by H. Tang, T. Kakum, O. Roots). Contract of Estonian Ministry of Environment No. K-11-1-2005/1896. 2005. P. 1-41 + app. [in Estonian].

20. Monitoring and research of hazardous substances in inland water bodies (Compiled by O. Roots). Estonian Environmental Research Center. Contract of Estonian Ministry of Environment No. K-13-6-2006/295. 2006. P. 1-20 + the results of chemical analysis (www.klab.ee/failid/109.pdf and www.klab.ee/failid/110.xls) [in Estonian].

21. Roose, A, Roots, $O$. Monitoring of priority hazardous substances in Estonian water bodies and the coastal Baltic Sea // BOREAL ENV. RES. 2005. Vol.10, No. 2. P. 89102.

Presented by $V$. Lahtvee

Received February 22, 2007 